International Journal of Hiology, Pharmacy and Allied Sciences (IJBPAS)

'A Bridge Betuen Caboratory and QRando'

WWW.ibpas.com

\title{
A REVIEW ON ISOLATION, IDENTIFICATION OF AMYLASE PRODUCED FROM SOIL BACTERIA
}

\author{
PATEL $D^{1}$, UPADHAYAY $D^{2}$, MARCHAWALA $F^{2}$, BHATTACHARYA $I^{2}$ AND \\ ANDHARE $\mathbf{P}^{2 *}$
}

1: Student, MSc Microbiology, Parul Institute of Applied Sciences, Parul University, Post Limda, Waghodia, Gujarat, 391760

2: Assistant Professor, Parul Institute of Applied Sciences, Parul University, Post Limda, Waghodia, Gujarat, 391760

*Corresponding Author: E Mail: Dr. Prasad Andhare: prasad.andhare82145@paruluniversity.ac.in; Tel: $+918200614350$

Received $19^{\text {th }}$ Jan. 2021; Revised 20 ${ }^{\text {th }}$ Feb. 2021; Accepted $19^{\text {th }}$ March 2021; Available online $1^{\text {st }}$ April 2021 https://doi.org/10.31032/IJBPAS/2021/10.4.1004

\begin{abstract}
Amylase can be gotten from a few growths, yeast, microorganisms and actinomycetes; nonetheless, compound from contagious and bacterial sources has overwhelmed applications in modern areas. The use of an amylase in starch handling and material enterprises because of its activity in higher temperature $\left(75-105^{\circ} \mathrm{c}\right)$ and impartial to antacid pH13. For the most part, creation of this chemical has been completed by lowered maturation. Among the bacterial sources Bacillus subtilis, Bacillus staerothermophilus, Bacillus amyloliquefaciens, Bacillus licheniformis, Bacillus acidocaldarius, Bifidobacterium bifidum and Bifidobacterium acerans are significant species. The current audit was centered around bacterial amylase and this survey evaluates the accompanying sections: Amylase, Microorganisms and amylases, Physiology of amylases are one among the foremost important industrial enzymes, which hydrolyze starch molecules to fine products like dextrins, maltose etc. In recent years, interest within the microbial production of enzyme has increased dramatically thanks to its widespread use in baking, food, textile, and detergent industry.
\end{abstract}


Amylase production by bacteria esp. by Bacillus species is of great importance nowadays. The purpose of current investigation is to isolate amylase producing Bacillus species from soil. Soil samples were collected from different areas of Gujarat.

Keywords: Amylase, starch, bacillus, soil sample, microorganisms, microbial production

\section{INTRODUCTION: -}

\subsection{Soil bacteria: -}

Microorganisms are a significant piece of the dirt microflora in view of their plenitude and the assortment of their metabolic exercises $[\mathbf{5 , 5 0 ]}$. They assume a vital part in the biogeochemical patterns of the fundamental components and of minor components and are consequently intensely ensnared in energy and supplement trades inside the dirt [52].

They additionally can possibly mirror the previous history of a given climate [10]. It is consequently basic to comprehend the interrelationships among microbes and their current circumstance by contemplating the primary and useful variety of soil bacterial networks and how they react to different common or man-made unsettling influences [12].

The variety of soil bacterial networks has been examined for a long-time utilizing strategies dependent on disengaging and refined the miniature living beings [15]. Such methods are known for their selectivity and are not viewed as illustrative of the degree of the bacterial network [15].

\subsection{Bacteria produce amylase: -}

Bacillus is a typical bacterial hotspot for mechanical amylase creation. Apparently,
Bacillus strains have been widely utilized modernly to create $\alpha$-amylase including $B$. amyloliquefaciens, $B . \quad$ subtilis, $\quad B$. licheniformis, B. stearothermophilus, $\quad B$. megaterium and B. circulans $[8, \mathbf{1 6}, 47,48$, 54].

Several bacteria have been shown are capable of producing a tremendous amount of alpha-amylase for industrial applications [19]. Amylases are enzymes that break down starch or glycogen [39]. There are different types of bacteria in soil that produce Amylase. The bacteria that are found in soil produce amylaseare Amycolatopsis, Aspergillus, Bacillus, Burkholderia, Enterobacter, Fusarium, Matsuebacter, Myxobacter, Nocardia, Penicillium, Pseudomonas, Rhodotorula, Streptomyces and Trichoderma.

Bacillus is a typical bacterial hotspot for mechanical amylase creation. Reportedly, bacillus strains have been extensively used industrially to produce $\alpha$ amylase including $B$. amyloliquefaciens, $B$. subtilis, B. licheniformis, B. stearothermophilus, $\quad B . \quad$ megaterium and $B$. circulans $[8,16,47,54]$ (Table 2). 
Table 1: Presence of different species of bacillus at different places

\begin{tabular}{|c|c|c|c|}
\hline S. No. & Bacillus species & Isolation source & Locality(city) \\
\hline 1 & Lysinibacillus fusiformis & Agricultural soil & Rumenka (https://www.google.com/url) \\
\hline 2 & Bacillus safensis & Non-agricultural soil & BanatskiDvor (https://www.google.com/url) \\
\hline 3 & Bacillus pumilus & Rhizosphere (wheat) & Bukovac (https://www.google.com/url) \\
\hline 4 & Lysinjbacillus fusiformis & Non-agricultural soil & Petrovaradin (https://www.google.com/url) \\
\hline 5 & Bacillus subtilis & $\begin{array}{c}\text { Rhizosphere } \\
\text { (sunflower) }\end{array}$ & BackiPetrovac(https://www.google.com/url) \\
\hline 6 & Bacillus cereus & Non-agricultural soil & Sangaj(https://www.google.com/url) \\
\hline 7 & Bacillus subtilis & Rhizosphere (maize) & Rimski Sancevi(https://www.google.com/url) \\
\hline 8 & Bacillus megaterium & $\begin{array}{c}\text { Rhizosphere } \\
\text { (pepper) }\end{array}$ & Rimski Sancevi(https://www.google.com/url) \\
\hline 9 & Bacillus megaterium & Rhizosphere (alfalfa) & Perlez(https://www.google.com/url) \\
\hline 10 & Lysinjbacillus fusiformis & Non-agricultural soil & Prancevo(https://www.google.com/url) \\
\hline 11 & Bacillus pumilus & Forest soil & Vrsacka kula(https://www.google.com/url) \\
\hline
\end{tabular}

\subsection{Benefits of Microbes in Soil}

- Decompose organic matter.

- Foster soil aggregate stability.

- Recycle and regulate carbon, nitrogen and phosphorous.

- Fix nitrogen for plant uptake.

- Increase the available plant root area for nutrient uptake.

- Degrade pesticides.

- Improve soil structure.

- Help control diseases.

\section{AMYLASES: -}

Amylases are extensively characterized into 3 subtypes and they are $\alpha, \beta$, and $\gamma$, in which the initial two have been the most broadly examined. $\alpha$-Amylase is a quicker acting chemical than $\beta$-amylase. The amylases follow up on $\alpha-1-4$ glycosidic bonds what's more, are in this manner additionally called glycoside hydrolases.

Amylases are enzymes which hydrolyze starch molecules to give diverse products including dextrin and progressively smaller polymers composed of glucose units [55]. These enzymes are of great significance in present day biotechnology with applications ranging from food, fermentation, and textile to paper industries[40]. Today a large number of microbial amylases are available commercially and they have almost completely replaced chemical hydrolysis of starch in starch processing industry [40].

Amylase is divided into two categories, endoamylases and exoamylases. Endoamylases catalyze hydrolysis in a random manner in the interior of the starch molecule. This action causes the formation of linear and branched oligosaccharides of various chain lengths. Exoamylases hydrolyze from the non-reducing end, successively resulting in short end products. Today a large number of enzymes are known which hydrolyze starch molecule into different products and a combined action of various enzymes is required to hydrolyze starch completely. 


\subsection{Structure and Function of amylase:}

The three-dimensional structures of $\alpha$ amylases from various sources such as Aspergillus oryzae, Aspergillus niger, porcine pancreas, barley, human saliva, Bacillus licheniformis, Bacillus stearothermophilus and Alteromonas haloplanctis have been determined [45].

Amylase substrates are universally accessible from modest plant sources, delivering the expected utilizations of the protein more copious as far as expenses. The final results of $\alpha$-amylase activity are oligosaccharides with changing length with a $\alpha$-arrangement and $\alpha$-limit dextrins, which comprise a combination of maltose, maltotriose, and stretched oligosaccharides of 6-8 glucose units that contain both $\alpha-1,4$ and $\alpha-1,6$ linkages $[\mathbf{5 2}, \mathbf{5 3}]$.

There are 2 types of amylase. They are bacterial amylase and fungal amylase.

\section{(a) Bacterial amylase: -}

Alpha-Amylase can be created by various types of microorganisms, yet for business applications alpha-amylase is principally got from the sort Bacillus.

\section{(b) Fungal amylase: -}

Contagious chemicals have the benefit of being discharged extracellularly. Moreover, the capacity of growths to infiltrate hard substrates encourages the hydrolysis cycle. It is noted that bacterial amylases have a more prominent thermostability than other alpha-amylases (alpha-1, 4-glucan 4glucanohydrolase, EC 3.2.1. 1) [23].

\subsection{Applications of amylase:}

Amylase can be acquired from a few organisms, yeast, microbes and actinomycetes; nonetheless, protein from contagious and bacterial sources has ruled applications in modern areas. The use of an amylase relies upon its novel qualities, for example, its activity design, substrate particularity, significant response items, ideal temperature, and ideal $\mathrm{pH} 12$. Bacterial $\alpha$-amylase favored for application in starch handling and material enterprises because of its activity at higher temperature $\left(75-103^{\circ} \mathrm{C}\right)$ and impartial on $\mathrm{pH} 13$. For the most part, creation of this catalyst has been completed by lowered maturation. Among the bacterial sources Bacillus subtilis, Bacillus staerothermophilus, Bacillus amyloliquefaciens, Bacillus licheniformis, Bacillus acidocaldarius, Bifidobacterium bifidum and Bifidobacterium acerans are significant species. The microbial amylases have totally supplanted substance hydrolysis of starch in starch handling industry [2]. Most significant hereditary designing continue to present recombinant $\alpha$-amylase can imply transmission of $\alpha$ amylase quality from bacillus species to other microbial host (Table 2) [3]. 
Table 2: Application of amylase

\begin{tabular}{|l|c|c|}
\hline Enzyme & Source & Application \\
\hline Amylase & Fungal & $\begin{array}{c}\text { Reduction of bulk viscosity, Acceleration of fermentation, Maintenance of } \\
\text { freshness }\end{array}$ \\
\hline Amylase & Fungal/Bacteria & Mashing(Crushing,Squashing,Smashing) \\
\hline Amylase & Fungal & Precooked baby food, breakfast foods \\
\hline Amylase & Fungal/Bacteria & Manufacture of syrup \\
\hline Amylase & Halobacillus & Biotechnological- based food, detergent, and pharmaceutical industries [31]. \\
\hline Amylase & Bacteria & Short growth period, biochemical diversity [36]. \\
\hline Amylase & Fungal & Pharmaceutical aid for the treatment of digestive disorders [39]. \\
\hline Amylase & Fungal & Manufacture of high maltose syrups \\
\hline Amylase & Bacillus subtilis & Designing fabrics, liquefaction of starch during corn and chocolate syrups. \\
& & Starch hydrolysis [26]
\end{tabular}

\section{INDUSTRIAL APPLICATION OF $\alpha$ -} AMYLASE

\subsection{Starch conversion:}

The most far and wide utilizations of $\alpha$ amylases are in the starch business, wich are utilized for starch hydrolysis in the starch liquefaction measure that converts starch into fructose and glucose syrups [35].

The enzymatic change of all starch incorporates: gelatinization, which includes the disintegration of starch granules, subsequently framing a thick suspension; liquefaction, which includes fractional hydrolysis and misfortune in consistency; and saccharification, involving the production of glucose and maltose via further hydrolysis $[\mathbf{2 2}, \mathbf{4 2}]$.

Initially, $\quad$ the $\alpha$-amylase of Bacillus amyloliquefaciens was used but it has been replaced by the $\alpha$-amylase of Bacillus stearothermophilus or Bacillus

licheniformis [51]. The enzymes from the Bacillus species are of special interest for large-scale biotechnological processes due to their remarkable thermostability and because efficient expression systems are available for these enzymes[42].

\subsection{Detergent industry:}

Amylases are the second type of enzymes used in the formulation of enzymatic detergent, and $90 \%$ of all liquid detergents contain these enzymes[22, 24, 30].These enzymes are used in detergents for laundry and automatic dishwashing to degrade the residues of starchy foods such as potatoes, gravies, custard, chocolate, etc. to dextrins and other smaller oligosaccharides [33,37].

Amylases have movement at lower temperatures and basic $\mathrm{pH}$, keeping up the fundamental strength under cleanser conditions and the oxidative dependability of amylases is perhaps the main models for their use in detergents where the washing environment is very oxidizing $[\mathbf{9 , 2 8}]$. Instances of amylases utilized in the cleanser business are gotten from Bacillus or Aspergillus [30].

\subsection{Fuel alcohol production:}

Ethanol is the most utilized liquid biofuel. For the ethanol creation, starch is the most utilized substrate because of its low cost 
and effectively accessible crude material in many areas of the world [9]. The bioconversion of starch into ethanol includes liquefaction and saccharification, where starch is changed over into sugar utilizing an amylolytic microorganism or compounds, for example, $\alpha$-amylase, trailed by aging, where sugar is converted into ethanol using an ethanol fermenting microorganism such as yeast Saccharomyces cerevisiae [32,38].

To acquire another yeast strain that can straightforwardly create ethanol from starch without the requirement for a different saccharifying measure, protoplast combination was performed between the amylolytic yeast Saccharomyces fibuligera and S. cerevisiae [9].

Among microscopic organisms, $\alpha$-amylase got from thermoresistant microbes like Bacillus licheniformis or from designed strains of Escherichia coli or Bacillus subtilis is utilized during the initial step of hydrolysis [44].

\subsection{Food industry:}

Amylases are extensively employed in processed-food industry such as baking, brewing, preparation of digestive aids, production of cakes, fruit juices and starch syrups [11]. And then creating fermentable mixtures, $\alpha$-amylases likewise have an enemy of staling impact in bread heating, and they improve the delicateness maintenance of prepared merchandise, expanding the timeframe of realistic usability of these items [22,51].

Currently, a thermostable maltogenic amylase of Bacillus stearothermophilus is used commercially in the bakery industry [51]. Amylases are also used for the clarification of beer or fruit juices, or for the pretreatment of animal feed to improve the digestibility of fiber $[\mathbf{1 8 , 2 0 , 5 1 ]}$.

\subsection{Textile industry:}

Amylases are utilized in material industry for desizing measure. Starch is subsequently eliminated from the woven texture in a wet measure in the material completing industry. Desizing includes the expulsion of starch from the texture which fills in as the reinforcing specialist to forestall breaking of the twist string during the weaving cycle.

The $\alpha$-amylases remove selectively the size and do not attack the fibres $[\mathbf{1 4}, \mathbf{2 2}]$. Amylase from Bacillus stain was utilized in material businesses for a serious long time.

\subsection{Paper industry:}

The utilization of $\alpha$-amylases in the mash and paper industry is for the adjustment of starch of covered paper, i.e. for the production of low-viscosity, high molecular weight starch [22, 51]. The covering treatment serves to make the outside of paper adequately smooth and solid, to improve the composing nature of the paper. The size enhances the stiffness and strength in paper $[7,22]$. 


\section{MICROBIAL AMYLASES: -}

They are enzymes which are produced from microorganisms to hydrolyze starch. Main 3 types of microbial amylases. They are $\alpha$ - amylase, $\beta$ - amylase and glucoamylase. Each of this amylase has a unique way of acting on starch to yield simple glucose monomers. Sources of amylase are plants, animalsand microorganisms but more attention is given to microorganisms because amylases produce by them have greater thermal stability as well as it gives rise to different sugar profile and finally meets with industrial demands. The 2 major groups of microorganisms play pivotal role in amylase production including bacteria and fungi. In amylase production the starch is the substrate used in it. The microbial amylases are greatly applied in pharmaceutical, food, chemical, paper and distilling industries.

\subsection{Advantages and uses of microbial amylases: -}

- Production of amylase is in economical bulk production capacity.

- Microbes are also easy to manipulate to obtain enzyme of desired characteristics.

- The microbial amylases meet industrial demands a large number of them are available

commercially.

- "Bacillus lecheniformis", "Bacillus amyloliquifaciens", “Aspergillus niger".

- Useful application in food, brewing, textile, detergents and pharmaceuticals industries.

- In the productions of detergents, they are applied to improve cleaning cleaning effect and are also used for starch desizing in textile industry.

- They are mainly employed for starch liquefaction (a process of dispersion insoluble starch in aqueous solution) to reduce their viscosity, production of maltose, oligosaccharide mixture.

\section{STRACH}

Starch is a significant constituent of the human eating regimen and, for this design, is utilized artificially and enzymatically handled into a wide range of items, for example, starch hydrolysates, glucose syrups, fructose, maltodextrin subsidiaries or cyclodextrins, utilized in food industry [1]. Despite the enormous number of plants ready to create starch, a couple of plants are significant for modern starch preparing bacillus [9].

The major modern sources are maize, custard, potato, and wheat, however 
constraints, for example, low shear opposition, warm obstruction, and warm disintegration and high propensity towards retrogradation limit its utilization in some mechanical food applications [51]. Starch contributes extraordinarily to the textural properties of numerous nourishments and is generally utilized in food and mechanical applications as a thickener, colloidal stabilizer, gelling specialist, building specialist and water maintenance specialist [25].

Starch is a polymer of glucose connected to another through the glycosidic bond. Two kinds of glucose polymers are available in starch: amylase and amylopectin [41]. Amylose and amylopectin have various structures and properties [43]. Amylose is a direct polymer comprising of up to 6000 glucose units with $\alpha-1,4$ glycosidic bonds [37]. Amylopectin comprises of short $\alpha-1,4$ connected to straight chains of 10-60 glucose units and $\alpha-1,6$ connected to side chains with 15-45 glucose units [34].

Solvent starch synthase is viewed as liable for the combination of unit chains of amylopectin [49]. $\alpha$-Amylase can divide $\alpha$ 1, 4 glycosidic bonds present in the inward piece of the amylose or amylopectin chain[51].

\section{7. $\alpha$-AMYLASE: -}

Amylases are quite possibly the main modern chemicals that have a wide assortment of uses going from change of starch to $\alpha$-Amylases (E.C. 3.2.1.1.) are starchdegrading chemicals that catalyze the hydrolysis of inner $\alpha-1$, 4-O-glycosidic bonds in polysaccharides with the maintenance of $\alpha$-anomeric design in low sub-atomic weight items, such glucose, maltose and maltotriose units [6]. These proteins have $8(\alpha / \beta)$ or TIM barrel structure containing the synergist site deposits and Contain of four exceptionally monitored areas in their essential sugar syrups, to the creation of cyclodextrins for the drug business [46].

\section{8. $\beta$-AMYLASE: -}

This is an enzyme with systematic name 4alpha-D-glucan maltohydrolase[4, 17,29]. This enzyme acts on starch, glycogen and related to polysaccharides and oligosaccharide produced by an inversion. Many microbes also produce amylase to degrade extracellular starch.

\section{GLUCOAMYLASE: -}

It is one of the oldest and widest used biocatalysts in food industry. Major application is to saccharification of partially processed starch/dextrin to glucose that is essential substrate for numerous fermentation processes and a range of food and beverage industries.

\section{ACKNOWLEDGEMENT}

It is our privilege and honour to express our sincerest gratitude to the Parul University, Vadodara, Gujarat for providing me all the 
necessary support and facilities including state of the art infrastructural facilities with advanced technological scientific laboratories and everything else that was required to carry out this work.

\section{REFERENCES}

[1] Agrawal, $\quad$ M.; $\quad$ Pradeep, $\quad$ S.; Chandraraj, K.; Gummadi, S.N. (2005). Hydrolysis of starch by amylase from Bacillus sp. KCA102: a statistical approach. Process Biochemistry 40, 2499 - 2507.

[2] Asgher, M. Asad, M.J. Rahman, S.U. Legge, R.L. 2007. A thermostable $\alpha$ amylase from a moderately thermophilic Bacillus subtilis strain for starch processing. J Food Process Eng, 79:950- 955.

[3] Asoodeh, A.; Chamani, J.; Lagzian, M. (2010). A novel thermostable, acidophilic alpha-amylase from a new thermophilic "Bacillus sp. Ferdowsicous" isolated from Ferdows hot mineral spring in Iran: Purification and biochemical characterization. Int $\mathrm{J} \quad$ Biol Macromol 46, 289-297.

[4] Balls AK, Walden MK, Thompson RR (March 1948). "A crystalline beta-amylase from sweet potatoes". The Journal of Biological Chemistry. 173 (1): 9-19. PMID 18902365
[5] Blaine Metting Jr F. (Ed.), Soil Microbial Ecology, Marcel Dekker, Inc, New York, 1992, pp. 3-95.

[6] Brayer, G.D. Luo, Y. Withers, S.G. 1995. The structure of human pancreatic alphaamylase at $1.8 \mathrm{~A}$ resolution and comparisons with related enzymes. Protein Sci. 4:17301742.

[7] Bruinenberg P.M., Hulst A.C., Faber A., Voogd R.H A process for surface sizing or coating of paper. In: European Patent Application. 1996.

[8] Brumm P.J., Hebeda R.E., and Teague W.M. Purification \& characterization of commercialized, cloned magisterium $\alpha$-amylase. Part I: purification \& hydrolytic properties. Starch.

43:319-323 (1991).

[9] Chi, M.; Chen, Y.; Wu, T.; Lo, H.; Lin, L. (2009). Engineering of a truncated $\alpha$-amylase of Bacillus sp. strain TS-23 for the simultaneous improvement of thermal and oxidative stabilities. $J$ Biosci. Bioeng.

[10] Cole S.T., Saint Girons I., Bacterial genomics, FEMS Microbiol. Rev. 14 (1994) 139-160.(3)

[11] Coute S.R., Sanroman M.A. Application of solid- state fermentation to food industry. A 
review Journal of food engineering. 2006; 76:291-302.

[12] Dunbar J., Shannon T., Barns S.M., Davis J.A., Kuske C.R., Levels of bacterial community diversity in four arid soils compared by cultivation and 16S rRNA gene cloning, Appl. Environ. Microbiol. 65 (1999) 1662-1669.

[13] Falholt, P. (1998).

[14] Feikenhauer H. Anerobicdigest of desizing wastewater: influence of pretreatment and anionic surfactant on degradation and intermediate accumulation. Enzyme Microb. Technol 2003; 33; 250-258.

[15]Felske A., Akkermans A.D.L., Spatial homogeneity of abundant bacterial 16S rRNA molecules in Grassland soils, Microbial Ecol. 36 (1998) 31-36.

[16]Fogarty W.M., and Kelly C.T. Amylase, amyloglucosidase and related glucanases. Rose A.H. Economic Microbiology, Microbial Enzymes and Bioconversion, New York Academic Press Inc, vol. 5. Pp. 115-170 (1980).

[17] French D (1960). " $\beta$-Amylases". In Boyer PD, Lardy H, Myrbaumlck K (eds.). The Enzymes. 4 (2nd ed.). New York: Academic Press. pp. 345-368.
[18] Gavrilescu, M.; Chisti, Y. (2005). Biotechnology-a sustainable alternative for chemical industry. Biotechnol $A d v$ 23, 471-499.

[19] Gazali FM, Suwastika IN. Thermostable $\alpha$-amylase activity from thermophilic bacteria isolated from Bora Hot Spring, Central Sulawesi. Journal of Physics: Conference Series. 2018; doi: 10.1088/1742-6596/979/1/012001.

[20] Ghorai, S.; Banik, S.P.; Verma, D.; Chowdhury, S.; Mukherjee, S.; Khowala, S. (2009). Fungal biotechnology in food and feed processing. Food Res. Int. 42, 577587Glymph, J.L.;

[21] Goyal, N.; Gupta, J.K.; Soni, S.K. (2005). A novel raw starch digesting thermostable $\alpha$-amylase from Bacillus sp. I-3 and its use in the direct hydrolysis of raw potato starch. Enzyme Microb. Technol. 37, 723-734.

[22] Gupta R, Gigras P, Mohapatra H, Goswami V.K, Chauhan B. 2003. Microbial aamylases: a biotechnological perspective. Process Biochem, 38:1599-1616.

[23] Hartman P. A. (1955)

[24] Hmidet N., El-Hadj Ali N., Haddar A., Kanoun S., Alya S., Nasri M. Alkaline proteases and thermostable alpha amylase co-produced by 
Bacillus licheniformis NH1:

Characterization and potential application as detergent additive. Biochemical Engineering Journal. 2009; 71-79.

[25] Jaspreet Singha， J.; Kaurb， L.; McCarthy, O.J. (2007). Factors influencing the physico-chemical, morphological, thermal and rheological properties of some chemically modified starches for food applications-A review. Food Hydrocolloids 21, 1-22.

[26] Kavanagh, F. "Analytical Microbiology" Vol.1. Academic Press (1962), London.

[27] Kelly, C.T., Bi-phasic production of aamylase of Bacillus flavothermus in batch fermentation. Biotechnol. Lett. 19: 675-677, 1980.

[28] Kirk, O.; Borchert, T.V.; Fuglsang, C.C. (2002). Industrial enzyme applications. CurrOpinBiotechnol 1 3, 345-351.

[29] Manners DJ (1962). "Enzymic synthesis and degradation of starch and glycogen". Advances in Carbohydrate Chemistry. 17: 371430. doi:10.1016/s0096-5332(08)60139-3. ISBN 9780120072170.

[30] Mitidieri, S.; Souza Martinelli, A.H.; Schrank, A.; Vainstein, M.H. (2006). Enzymatic detergent formulation containing amylase from Aspergillus niger: a comparative study with commercial detergent formulations. Bioresour Technol 97, 1217-1224.

[31] Mohapatra, B.R.; Banerjee, U.C.; Bapuji, M. (1998). Characterization of a fungal amylase from Mucor sp. Associated with the marine sponge Spirastrella sp. J.Biotechno. 60, 113-117

[32] Moller, K.; Sharif, M.Z.; Olsson, L. (2004). Production of fungal alphaamylase by Saccharomyces kluyveri in glucose-limited cultivations. $J$ Biotechnol 111, 311-318.

[33] Mukherjee, A.K.; Borah, M.; Raí, S.K. (2009). To study the influence of different components of fermentable substrates on induction of extracellular $\alpha$-amylase synthesis by Bacillus subtilis DM-03 in solidstate fermentation and exploration of feasibility for inclusion of $\alpha$ amylase in laundry detergent formulations. Biochem. Eng. J. 43, 149-156.

[34] Muralikrishna, G.; Nirmala, M. (2005). Cereal $\alpha$-amylases - an overview. Carbohydrate

Polymers 60, 163-173.

[35] Nielsen, J.E.; Borchert, T.V. (2000). Protein engineering of bacterial alpha-amylases. Biochem. Biophys Acta 1543, 253-274. 
[36] Oliveira, A., Oliveira, L., Andrade, J and Junior, A. 2007. Rhizobial amylase production using various starchy substances as carbon substrates. Brazilian Journal of Microbiology, 38: 208 - 216.

[37] Olsen, H.S.O.; Falholt, P. (1998). The Role of Enzymes in Modern Detergency. Journal of Surfactants and Detergents 1, 555-567.

[38] Öner, E.T. (2006). Optimization of ethanol production from starch by an amylolytic nuclear petite Saccharomyces cerevisiae strain. Yeast 23, 849-856.

[39] Pandey, A., Nigam, P., Soccol, C. R., Soccol, V. T., Singh, D and Mohan, R. 2000. Advances in microbial amylases. Biotechnology and Applied Biochemistry, 31: 135 152.

[40] Pandey, A., Nigam, P., Soccol, C. R., Soccol, V. T., Singh, D and Mohan, R. 2013. Advances in microbial amylases. Biotechnology and Applied Biochemistry, 31: 135 152.

[41] Payan, F. (2004). Structural basis for the inhibition of mammalian and insect alpha-amylases by plant protein inhibitors. Biochem. Biophys. Acta. 1696, 171-180.

[42] Prakash, O.; Jaiswal, N. (2009). alpha-Amylase: An Ideal
Representative of Thermostable Enzymes. Appl. Biochem. Biotechnol. 5(2): 258-271.

[43] Rajagopalan, G.; Krishnan, C. (2008). Alpha-amylase production from catabolite derepressed Bacillus subtilis KCC103 utilizing sugarcane bagasse hydrolysate. Bioresour Technol. 99, 3044-3050.

[44] Sanchez, O.J.; Cardona, C.A. (2008). Trends in biotechnological production of fuel ethanol from different feedstocks. Bioresour Technol 99, 5270-5295.

[45] Suvd, D., Fujimoto, Z., Takase, K., Matsumura, M., and Mizuno, $\mathrm{H}$. 2001. Crystal structure of Bacillus stearothermophilus amylase: possible factors determining thermostability. Journal of Biochemistry (Tokyo), 129: 461 468.

[46] Svensson, B. 1994. Protein engineering in the $\alpha$-amylase family; catalytic mechanism, substrate specificity, and stability. Plant Mol. Biol. 25:141-157.

[47] Takasaki Y. An amylase producing maltotetrose and from maltopentose from circulans. Agric Biol Chem. 47:2193-2199 (1983).

[48] Takasaki Y. An amylase producing maltotriose from subtilis. Agric Bio. Chem. 49:1091-1097 (1985). 
[49] Tester, R.F.; Karkalas, J.; Qi, X. (2004). Starch-composition, fine structure and architecture. J. Cereal Sci. 39, 151-165.

[50] Torsvik V., Goskøyr J., Daae F.L., High diversity in DNA of soil bacteria, Appl. Environ. Microbiol. 56 (1990) 782-787(12)

[51] Van der Maarel, M.J.; Van der Veen, B.; Uitdehaag, J.C.; Leemhuis, H.; Dijkhuizen, L. (2002). Properties and applications of starch-converting enzymes of the alpha-amylase family. J Biotechnol 94, 137-155.

[52] Ward-Raynet N., Rainey F.A et al., 1995.

[53] Whitcomb, D.C.; Lowe, M.E. (2007). Human pancreatic digestive enzymes. Dig Dis Sci 52, 1-17.

[54] Wind R.D., Buitelaar R.M.G., Huizing H.J., and Dijkhuizen L. Characterization of a new Bacillus stearothermophilus isolate: a highly thermostable $\alpha$-amylase producing strain. Appl Microbiol Biotechnol. 41:155-162 (1994).

[55] Windish, W. W and Mhatre, N.S. 2012. Microbial amylases. In: Wayne WU, editor. Advances in applied microbiology, vol. 7. New York: Academic Press, 2005: 273 304. 